Sketsa Bisnis Volume (08) No (02) (2021) pp (112-122)
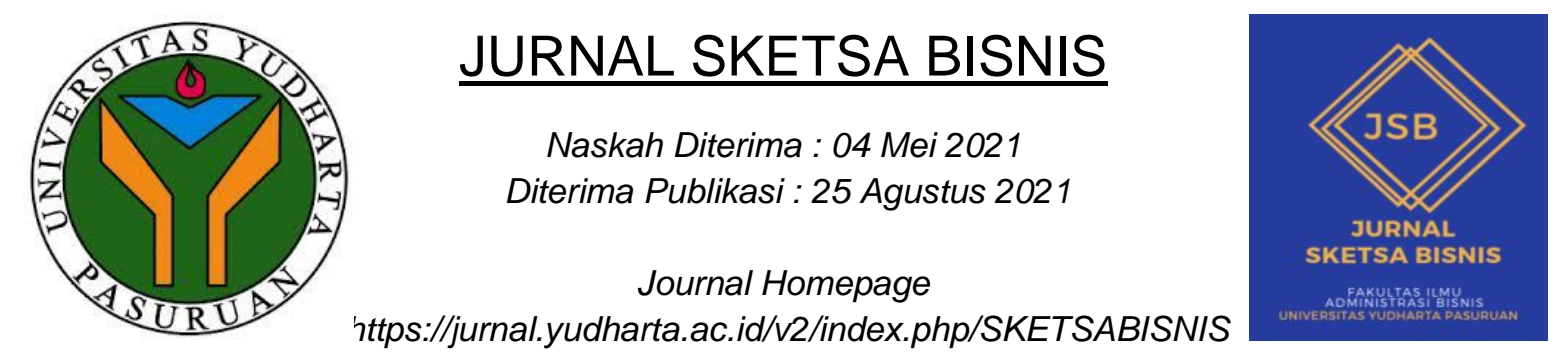

\title{
Pengaruh Motivasi, Lingkungan Kerja dan Disiplin Kerja Terhadap Kinerja Karyawan Studi Pada Dinas Perindustrian dan Perdagangan Kabupaten Malang
}

\section{Sinollah*, Zaenulloh Amin}

1.2 Universitas Islam Raden Rahmat Malang, Indonesia, sinollah@gmail.com

\begin{abstract}
This study aims to determine and analyze the effect of motivation, work environment and work discipline on job satisfaction at Dinas Perindustrian dan Perdagangan (Disperindag) Kabupaten Malang. To achieve this goal, this study uses quantitative methods using multiple linear regression analysis. The results showed that work motivation had no significant effect on employee performance, work environment had no significant effect on employee performance, and work discipline had a significant effect on employee performance. Simultaneously the variables of motivation, work environment and work discipline have a significant effect on employee performance at Dinas Perindustrian dan Perdagangan (Disperindag) Kabupaten Malang.
\end{abstract}

Keywords: Motivation, Work Environment, Work Discipline and Employee Performance

\section{Abstrak}

Penelitian ini bertujuan untuk mengetahui dan menganalisis pengaruh motivasi, lingkungan kerja dan disiplin kerja terhadap kepuasan kerja di Dinas Perindustrian dan Perdagangan (Disperindag) Kabupaten Malang. Untuk mencapai tujuan tersebut, penelitian ini menggunakan metode kuantitatif dengan menggunakan analisis regresi linier berganda. Hasil penelitian menunjukkan bahwa motivasi kerja tidak berpengaruh signifikan terhadap kinerja karyawan, lingkungan kerja tidak berpengaruh signifikan terhadap kinerja karyawan, dan disiplin kerja memiliki pengaruh signifikan terhadap kinerja karyawan. Secara simultan variabel motivasi, lingkungan kerja dan disiplin kerja berpengaruh signifikan terhadap kinerja karyawan di Dinas Perindustrian dan Perdagangan (Disperindag) Kabupaten Malang.

Kata Kunci: Motivasi, Lingkungan Kerja, Disiplin Kerja dan Kinerja Karyawan

*) Penulis Korespondensi: sinollah@gmail.com 


\section{Pendahuluan}

Setiap perusahaan atau organisasi harus memiliki karyawan yang mempunyai kinerja baik supaya dapat meningkatkan hasil kerja yang baik dan memberikan potensi kemajuan yang lebih besar suatu perusahaan atau oganisasi dalam mencapai sebuah tujuan. Kinerja menurut Mangkunegara (2017) adalah "hasil kerja secara kualitas dan kuantitas yang dicapai oleh seseorang pegawai dalam melaksanakan tugasnya sesuai dengan tanggung jawab yang diberikan kepadanya". Menurut Mangkunegara (2017) faktor-faktor yang mempengaruhi kinerja karyawan meliputi factor kemampuan (Ability) dan factor Motivasi (Motivation).

Secara psikologis, kemampuan (ability) terdiri dari kemampuan potensi (IQ) dan kemampuan reality (Knowledge+skil). Artinya, pemimpin dan karyawan yang memiliki IQ di atas rata-rata (110-120) apalagi IQ superior, very superior, gifted dan genius dengan pendidikan yang memadai untuk jabatannya dan terampil dalam mengerjakan pekerjaan sehari-hari, maka akan lebih mudah mencapai kinerja maksimal. Motivasi diartikan suatu sikap (attitude) pimpinan dan karyawan terhadap situasi kerja di lingkungan organisasinya. Mereka yang bersikap positif terhadap situasi kerjanya akan menunjukkan motivasi kerja tinggi dan sebaliknya jika mereka bersikap negative terhadap situasi kerjanya akan menunjukkan motivasi kerja rendah. Situasi kerja yang dimaksud mencakup antara lain hubungan kerja, fasilitas kerja, iklim kerja, kebijakan pimpinan, pola kepemimpinan kerja dan kondisi kerja.

Selain itu, menurut Timpe (1992), kinerja juga dapat dipengaruhi oleh faktor-faktor kinerja terdiri dari faktor internal dan faktor eskternal. Faktor Internal yaitu faktor yang dihubungkan dengan sifat-sifat seseorang. Misalnya, kinerja seseorang baik disebabkan karena mempunyai kemampuan tinggi dan seseorang itu tipe pekerja keras, sedangkan seseorang mempunyai kinerja jelek disebabkan orang tersebut mempunyai kemampuan rendah dan orang tersebut tidak memiliki upaya-upaya untuk memperbaiki kemampuannya.

Faktor eksternal yaitu faktor-faktor yang mempengaruhi kinerja seseorang yang berasal dari lingkungan. Seperti perilaku, sikap, dan tindakan-tindakan rekan kerja, bawahan atau pimpinan, fasilitas kerja dan iklim organisasi.

Selain itu kinerja juga dapat dipengaruhi oleh motivasi, lingkungan kerja, dan disiplin kerja. Hal ini dapat dilihat dari penelitian yang dilakukan oleh Ekhsan (2019), Kusniawati dkk (2014), Josephine dan Harianti (2017), Suwanto (2019), dan Abdulah (2019) yang menunjukkan adanya pengaruh positif signifikan dari variabel motivasi, lingkungan kerja dan disiplin kerja terhadap kinerja karyawan. 
Motivasi merupakan suatu dorongan dari dalam diri seseorang senagai landasan yang mendasari rasa semangat kerja dalam melakukan sesuatu atau mengarahkan perilaku seseorang. Setiap perusahaan atau organisasi tentunya memerlukan SDM yang mempunyai motivasi yang tinggi supaya SDM tersebut memberikan seluruh kemampuannya agar menghasilkan kinerja yang baik sehingga mecapai prestasi kerja yang bagus. Menurut Hasibuan (2005) motivasi berasal dari kata latin movere yang berarti dorongan atau pemberian daya penggerak yang menciptakan kegairahan kerja seseorang agar mereka mau bekerja sama, bekerja efektif, dan terintgrasi dengan segala daya upayanya untuk mencapai kepuasan. Motivasi dalam manajemen hanya ditunjukkan pada sumber daya manusia (SDM) umumnya dan bawahan khususnya. Pentingna motivasi karena motivasi adalah hal yang menyebabkan, menyalurkan, dan mendukung perilaku manusia supaya mau bekerja giat dan antusias mencapai hasil yang optimal.

Disamping motivasi, ada juga lingkungan kerja merupakan salah satu faktor yang secara tidak sadar dan secara tidak langsung dapat mempengaruhi kinerja karyawan. Lingkungan kerja juga menjadi faktor yang bisa meningkatkan kinerja karyawan atau bahkan menurunkan kinerja karyawan. Apabila lingkungan kerja tempat para karyawan bekerja itu baik dan nyaman, maka akan memberikan rasa kenyamanan dan aman yang dirasakan oleh para karyawan untuk dapat bekerja dengan maksimal. Sebaiknya, jika lingkungan kerja tidak baik maka kemampuan karyawan menghasilkan kinerja yang baik akan minim sekali. Lingkungan kerja tersebut mencakup hubungan kerja yang terbentuk anara sesama pegawai, hubungan kerja bawahan terhadap atasan, dan lingkungan fisik disuatu perusahaan atau organisasi. Menurut Nitisemito (2014) lingkungan kerja adalah segala sesuatu yang ada disekitar para pekerja dan yang dapat mempengaruhi diri pekerja dalam menjalankan tugas-tugas yang dibebankan kepadanya. Hal ini semakin diperkuat dengam pendapat Ahyari (2014) bahwa lingkungan kerja adalah berkaitan dengan segala sesuau yang berada disekitar pekerjaan dan yang dapat mempengaruhi karyawan dalam melaksanakan tugasnya seperti pelayanan karyawan, kondisi kerja, dan hubungan karyawan di dalam perusahaan yang bersangkutan.

Selain motivasi dan lingkungan kerja ada juga disiplin kerja merupakan suatu sikap dan perilaku seseorang yang menunjukkan kepatuhan, kesetiaan, ketaatan, keteraturan dan ketertiban terhadap peraturan perusahaan atau organisasi dan norma-norma sosial yang berlaku. Menegakkan disiplin kerja sangat penting bagi perusahaan atau organisasi. Adanya disiplin kerja akan menghasilkan dan menjamin terpeliharanya tata tertib dan kelancaran pelaksanaan kerja perusahaan, sehingga memperoleh hasil yang baik. Sedangkan bagi karyawan, disiplin kerja sangat berpengaruh pada diri karyawan yang akan memberikan dampak suasana kerja yang baik, menyenangkan sehingga akan 
menambah semangat dalam melaksanakan tugas-tugas dan tanggung jawabnya. Menurut Sutrisno (2009) disiplin kerja adalah "perilaku seseorang yang sesuai dengan peraturan, prosedur kerja yang ada atau disiplin adalah sikap, tngkah laku dan perbuatan yang sesuai dengan peraturan dari perusahaan atau organisasi baik tertulis maupun yang tidak tertulis".

Salah satu organisasi atau perusahaan yang didalamnya tentu memerlukan dan menerapkan variabel motivasi, lingkungan kerja dan disiplin kerja adalah Dinas Perindustrian dan Perdagangan Kabupaten Malang. Dinas Perindustrian dan Perdagangan Kabupaten Malang merupakan organisasi perangkat daerah yang dibentuk berdasarkan Peraturan Bupati Malang Nomor 41 Tahun 2016 tentang Kedudukan, Susunan Organisasi, Tugas dan Fungsi, serta Tata Kerja Dinas Perindustrian dan Perdagangan Kabupaten Malang merupakan OPD dengan tipe A dan melaksanakan fungsi penunjang urusan pemerintahan bidang perindustrian dan perdagangan.

Adapun tujuan pembangunan Dinas Perindustrian dan Perdagangan Kabupaten Malang adalah meningkatkan peranan Industri dalam perekonomian sehingga mampu meningkatkan lapangan kerja dan kesempatan usaha serta meningkatkan produktivitas dan mampu bersaing dipasar global, meningkatkan efisiensi perdagangan dalam negeri, pengawasan peredaran barang/jasa dan pengembangan ekspor serta meningkatkan kualitas pelayanan dan mewujudkan pasar yang baik. Maka dari itu, untuk mewujudkan tujuan tersebut perlunya sumber daya manusia (SDM) yang berkualitas baik dan mengasilkan hasil kinerja yang bagus dan maksimal. Kinerja karyawan dapat dipengaruhi oleh beberapa faktor seperti motivasi, lingkungan kerja, disiplin kerja, dan lain sebagainya.

Dalam fenomena yang terjadi di Dinas Peridustrian dan Perdagangan Kabupaten Malang, alasan penulis melakukan penelitian dengan judul "Pengaruh motivasi, lingkungan kerja dan disiplin kerja terhadap kinerja karyawan" selain karena ketertarikan penulis terhadap judul tersebut juga karena kebetulan penulis pernah melakukan Praktik Kerja Lapangan (PKL) di Dinas Peridustrian dan Perdagangan Kabupaten Malang yang menurut penulis dimana tingkat motivasi, lingkungan kerja dan disiplin kerja masih kurang tinggi dan baik.

Berdasarkan uraian di atas, maka peneliti tertarik untuk melakukan penelitian dengan judul Pengaruh Motivasi, Lingkungan Kerja dan Disiplin Kerja terhadap Kinerja Karyawan pada Dinas Perindustrian dan Perdagangan Kabupaten Malang. 


\section{Kerangka Teori}

Sesuai dengan judul penelitian ini, konsep dalam penelitian ini terdiri dari 4 konsep, yaitu: kinerja pegawai, motivasi, lingkungan kerja dan disiplin kerja. Mangkunegara (2017) mendefinisikan kinerja karyawan adalah hasil kerja secara kualitas dan kuantitas yang dicapai oleh seseorang pegawai dalam melaksanakan tugasnya sesuai dengan tanggung jawab yang diberikan kepadanya. Faktor-faktor yang mempengaruhi kinerja menurut Siagian (2002) menyatakan bahwa kinerja karyawan dipengaruhi beberpa faktor, yaitu : kompensasi, lingkungan kerja, budaya organisasi, kepemimpinan, motivasi kerja, disiplin kerja, kepuasan kerja, komunikasi dan faktor-faktor lainnya.

Menurut Mulyasa (2003) motivasi merupakan "tenaga pendorong atau penarik yang menyebabkan adanya tingkah laku ke arah suatu tujuan tertentu. Peserta didik akan bersungguh-sungguh karena memiliki motivasi yang tinggi”. Sedangkan menurut Hamalik (1992) motivasi merupakan "perubahan energi dalam diri atau pribadi seseorang yang ditandai dengan timbulnya perasaan dan reaksi untuk mencapai tujuan". Dan menurut Sardiman (2006) motivasi merupakan "perubahan energi dalam diri seseorang yang ditandai dengan munculnya felling dan didahului dengan tanggapan terhadap adanya tujuan". Dalam berbagai penelitian motivasi kerja memiliki pengaruh yang signifikan terhadap kinerja karyawan seperti penelitian yang dilakukan oleh Abdulah (2019) menyimpulkan bahwa motivasi berpengaruh positif secara signifikan terhadap kinerja karyawan SMK Ksatrya Jakarta.

Selain motivasi, lingkungan kerja juga memiliki pengaruh yang signifikan terhadap kinerja karyawan pada penelitian yang dilakukan oleh Josephine dan Harianti (2017) hasil penelitian menyatakan bahwa variabel lingkungan kerja memiliki pengaruh signifikan terhadap kinerja karyawan PT. Trio Corporate Plastic (Tricopla). Lingkungan kerja adalah sesuatu yang berada disekitar para pekerja yang meliputi cahaya, warna, udara, suara serta musik yang mempengaruhi dirinya dalam menjalankan tugas-tugas yang dibebankan (Moekijat, 2002).

Disiplin kerja dapat didefinisikan sebagai suatu sikap menghormati, menghargai, patuh dan taat terhadap peraturan yamg berlaku, baik tertulis maupun tidak tertulis. Keith Davis (1985) mengemukakan bahwa "Dicipline is management action to enforce organization standards" berdasarkan pendapat Keith Davis, disiplin kerja dapat diartikan sebagai pelaksanaan manajemen untuk memperteguh pedoman-pedoman organisasi. Dalam berbagai penelitian variabel disiplin kerja memiliki pengaruh signifikan terhadap kinerja karyawan seperti penelitian yang dilakukan oleh Suwanto (2019) menyatakan 
bahwa variabel disiplin kerja mempunyai pengaruh yang signifikan terhadap kinerja karyawan Rumah Sakit Umum Tangerang Selatan .

\section{Metode}

Penelitian ini merupakan penelitian dengan menggunakan metode penelitian kuantitatif, Menurut Sugiyono (2010) metode peenelitian kuantitatif adalah "data penelitian berupa angka-angka dan analisis yang digunakan berupa statistik". Penelitian ini bertujuan untuk melakukan identifikasi apakah terdapat hubungan tertentu antar variabel, yaitu seberapa besar pengaruh antara satu variabel dengan variabel lainnya (Sekaran dan Bougie: 2010).

Penelitian ini dilakukan untuk meneliti terkait apakah terdapat pengaruh motivasi, lingkungan kerja dan disiplin kerja terhadap kinerja karyawan. Lokasi penelitian ini bertempat di Dinas Perindustrian dan Perdagangan Kabupaten Malang yang beralamatkan di Jl. Panji No. 119, Penarukan, Kecamatan Kepanjen Kabupaten Malang dengan sampel sebanyak 62 orang. Untuk memperoleh data, penelitian ini menggunakan kuesioner, wawancara dan observasi. Adapun untuk analisis data menggunakan analisis regresi berganda.

\section{Hasil Penelitian dan Pembahasan}

Sebelum dilakukan uji regresi, data diuji terlebih dahulu dengan uji validitas dan reliabilitas. Hasil menunjukkan bahwa semua data sudah valid karena hasil korelasi antara intem dengan total item mempunyai tingkat signifikansi lebih kecil dari 0,05 (Arikunto, 1995) dan reliabel karena hasil alpha Cronbach setiap variable lebih besar dari 0,6 (Arikunto, 1995). Berdasarkan hasil uji asumsi klasik bahwa data layak untuk dilakukan uji regresi linier berganda untuk mengetahui besarnya pengaruh antar variabel bebas terhadap variabel terikat dalam bentuk persamaan regresi linear berganda. Hasil uji t dan uji $F$ dapat dilihat dalam tabel berikut:

Tabel 1 Hasil Uji t

\begin{tabular}{|c|l|l|l|l|}
\hline No & \multicolumn{1}{|c|}{ Variabel } & \multicolumn{1}{c|}{ B } & \multicolumn{1}{c|}{ t } & \multicolumn{1}{c|}{ Sig t } \\
\hline 1 & Konstanta & 14.070 & 4.300 & .000 \\
\hline 2 & Motivasi & -.059 & -.989 & .327 \\
\hline 3 & Lingkungan Kerja & -.017 & -.229 & .820 \\
\hline 4 & Disiplin Kerja & .536 & 6.062 & .000 \\
\hline
\end{tabular}

Dependent Variable: Kinerja Karyawan

Sumber: Data primer, diolah dengan SPSS, 2020 
Tabel 2 Hasil Uji F

\begin{tabular}{|c|l|l|r|c|}
\hline No & \multicolumn{1}{|c|}{ Model } & Sum of Squares & F & Sig. \\
\hline 1 & Regression & 71.107 & 13.847 & $.000 \mathrm{a}$ \\
\hline 2 & Residual & 99.280 & & \\
\hline 3 & Total & 170.387 & & \\
\hline
\end{tabular}

Dependent Variable: Kinerja Karyawan

Sumber: Data primer, diolah dengan SPSS, 2020

Berdasarkan table 2 hasil perhitungan uji $F$ di atas, nilai $F$ hitung yang diperoleh sebesar 13.847 sedangkan nilai $F$ tabel sebesar 2.76 maka dapat diketahui nilai $F$ hitung (13.847) > F tabel (2.76) dengan tingkat signifikan 0,000 karena tingkat signifikan < dari 0,05, maka dapat disimpulkan bahwa variabel motivasi, lingkungan kerja, dan disiplin kerja secara simultan (bersama-sama) berpengaruh secara signifikan terhadap variabel kinerja karyawan.

Bedasarkan pada tabel 1 Uji t dengan ketentuan $\mathrm{a}=0.05$, df $=(n-k-1)$ atau (62-31) $=58$ sehingga diperoleh nilai $t$ tabel sebesar 1.672. Maka berdasarkan hasil dari tabel 1 uji t dan tabel 2 uji F diatas, dapat diketahui sebagai berikut:

\subsection{Pengaruh Motivasi (X1) terhadap Kinerja Karyawan (Y)}

Berdasarkan tabel 14. Uji t mengihasilkan nilai t tabel dari coeficients diperoleh angka 0.989 yang berarti bahwa t hitung < t tabel dengan angka $(0.989<1.672)$ dapat diuraikan t hitung lebih kecil daripada t tabel yang berarti signifikansi t hitung tidak sama dengan t tabel (1.672), maka Ho diterima dan Ha ditolak. Oleh karena itu, variabel motivasi $(\mathrm{X} 1)$ tidak berpengaruh signifikan terhadap variabel kinerja karyawan $(\mathrm{Y})$ pada Dinas Perindustrian dan Perdagangan (Disperindag) Kabupaten Malang.

Artinya motivasi bukanlah faktor yang dominan dalam meningkatkan kinerja karyawan Dinas Perindustrian dan Perdagangan (Disperindag) Kabupaten Malang. Hal ini terjadi karena pada realitanya di tempat penelitian ini terdapat dua tenaga kerja yaitu PNS dan kontrak, maka pada tenaga kerja yang masih dalam sistem kontrak dengan perpanjangan setahun dua kali dan dilakukan evaluasi sebelum tanda tangan kontrak, mereka merasa dengan proses yang begitu panjang dapat membuat jenuh dan dapat mempengaruhi motivasi mereka menjadi tidak baik dan tidak stabil.

Jadi hal ini tentu berlawanan atau bertentangan dengan teori yang ada, dimana menurut Mulyasa (2003) motivasi merupakan "tenaga pendorong atau penarik yang menyebabkan adanya tingkah laku ke arah suatu tujuan tertentu. Peserta didik akan bersungguh-sungguh karena memiliki motivasi yang tinggi".

Dengan hasil yang di dapatkan pada uraian diatas, maka hasil ini juga tidak sesuai dengan pendapat Robbins (2013). Robbins menyatakan bahwa motivasi adalah proses yang mempertimbangkan instensitas, arah perilaku, serta persistensi atau tingkat kegigihan atas suatu individu dalam upayanya untuk mencapai tujuan. Sementara 
pemahaman motivasi secara umum yaitu suatu dorongan atau alasan yang menjadi dasar semangat seseorang untuk mencapai tujuan tertentu.

Penelitian ini juga bertentangan dengan penelitian yang dilakukan oleh Ekhsan (2019) dan Kusjono dkk (2019) yang menunjukkan bahwa variabel motivasi berpengaruh signifikan terhadap kinerja karyawan PT. Syncrum Logistics.

\subsection{Pengaruh Lingkungan Kerja (X2) terhadap Kinerja Karyawan (Y)}

Berdasarkan tabel 14. Uji t menghasilkan nilai t tabel dari coeficients diperoleh angka 0.229 yang berarti bahwa t hitung $<$ t tabel dengan angka $(0.229<1.672)$ dapat diuraikan t hitung lebih kecil daripada t tabel yang berarti signifikansi t hitung tidak sama dengan t tabel (1.672), maka Ho diterima dan Ha ditolak. Oleh karena itu, variabel lingkungan kerja (X2) tidak berpengaruh signifikan terhadap variabel kinerja karyawan (Y) pada Dinas Perindustrian dan Perdagangan (Disperindag) Kabupaten Malang.

Hal ini terjadi karena pada realitanya di Dinas Perindustrian dan Perdagangan (Disperindag) karena lingkungan kerja seperti ruangan masih kurang membuat rasa nyaman seperti ada beberapa ruangan yang tidak sesuai dengan kapasitas dalam artian ruangan yang kecil ditempati oleh beberapa karyawan lebih sehingga terkesan terlihat sempit, penerangan yang masih kurang, jarak antar barang seperti lemari dan meja masih terlihat terlalu berdekatan.

Dengan adanya hasil seperti uraian diatas maka hal ini berlawanan atau berbanding terbalik dengan pengertian secara umum yang menyatakan bahwa lingkungan kerja merupakan komponen yang sangat penting bagi karyawan dalam melakukan aktifitas kerjanya. Pendapat tersebut juga dikemukakan oleh Nitisemito dalam Nuraini (2013) lingkungan kerja merupakan "segala sesuatu yang ada disekitar karyawan dan dapat mempengaruhi dalam menjalankan tugas yang diembankan. Hasil peneltian ini juga tidak sesuai dan tidak searti dengan penelitian yang dilakukan oleh Kusniawati dkk (2014) dan Josephine dkk (2017) yang menunjukkan bahwa lingkungan kerja berpengaruh signifikan terhadap kinerja karyawan.

\subsection{Pengaruh Disiplin Kerja (X3) terhadap Kinerja Karyawan (Y)}

Berdasarkan tabel 14. Uji t menghasilkan bahwa hasil uji signifikansi parsial (Uji t) diperoleh nilai $t$ hitung 6.062 yang artinya $t$ hitung $>t$ tabel $(6.062>1.672)$ dan menghasilkan nilai signifikansi variabel disiplin kerja sebesar 0,000 . Karena nilai signifikansi lebih kecil dari 0.05 maka keputusannya adalah $\mathrm{HO}$ ditolak dan Ha diterima yang artinya bahwa terdapat pengaruh positif signifikan variabel disiplin kerja terhadap kinerja karyawan pada Dinas Perindustrian dan Perdagangan (Disperindag) Kabupaten Malang. Maka dapat disimpulkan bahwa suatu kedisiplinan dan ketaatan para karyawan dalam bekerja menjalankan tugas yang diberikan oleh pimpinan berpengaruh terhadap 
kinerja kinerja karyawan untuk bekerja lebih keras dan baik dalam menyelesaikan tugasnya.

Dengan hasil peneltian ini maka penelitian ini memiliki pandangan atau hasil yang sejalan dengan penelitian yang dilakukan oleh Prasetyo (2019) dengan hasil penelitian menunjukkan bahwa terdapat pengaruh yang positif dan signifikan variabel disiplin kerja kerja terhadap kinerja karyawan dan penelitian ini sejalan dengan pendapat Keith Davis dalam Mangkunegara (2017) yang mengungkapkan bahwa disiplin kerja dapat diartikan sebagai pelaksanaan manajemen untuk memperteguh pedoman-pedoman organisasi.

\subsection{Pengaruh Motivasi (X1), Lingkungan Kerja (X2) dan Disiplin Kerja (X3) terhadap Kinerja Karyawan (Y)}

Berdasarkan tabel 15 hasil perhitungan uji $F$, menghasilkan nilai $F$ hitung yang diperoleh sebesar 13.847 sedangkan nilai $F$ tabel sebesar 2.76 maka dapat diketahui nilai F hitung (13.847) > F tabel (2.76) dengan tingkat signifikan 0,000 karena tingkat signifikan $<$ dari 0,05, maka dapat disimpulkan bahwa variabel motivasi, lingkungan kerja, dan disiplin kerja secara simultan (bersama-sama) berpengaruh secara signifikan terhadap variabel kinerja karyawan.

Hasil penelitian ini searti dan sejalan dengan hasil penelitian sebelumnya yang telah dilakukan oleh Pramadita dkk (2015) dan Novyanti (2015) yang menyatakan bahwa motivasi, lingkungan kerja dan disiplin kerja berpengaruh positif dan signifikan secara simultan terhadap kinerja karyawan

\section{Kesimpulan Dan Saran}

\subsection{Kesimpulan}

Berdasarkan hasil penelitian dan pembahasan yang telah dihasilkan dari penelitian yang dilakukan oleh peneliti mengenai pengaruh motivasi, lingkungan kerja dan disiplin kerja terhadap kinerja karyawan pada Dinas Perindustrian dan Perdagangan (Disperindag) Kabupaten Malang dapat ditarik kesimpulan bahwa secara parsial hanya disiplin kerja yang berpengaruh signifikan terhadap kinerja pegawai. Adapun motivasi dan lingkungan kerja tidak berpengaruh signifikan terhadap kinerja pegawai. Secara simultan motivasi, lingkungan kerja dan disiplin kerja berpengaruh signifikan pada kinerja pegawai pada Dinas Perindustrian dan Perdagangan Kabupaten Malang.

\subsection{Saran}

Hasil penelitian menunjukkan bahwa motivasi dan lingkungan kerja tidak memiliki pengaruh signifikan terhadap kinerja pegawai, namun demikian kedua variable tersebut perlu mendapatkan perhatian dari kepala dinas khususnya karena dengan lingkungan 
kerja yang nyaman pegawai akan nyaman pula dalam bekerja. Begitu juga dengan motivasi kerja perlu mendapatkan perhatian terutama motivasi dari dalam diri pegawai untuk meningkatkan kinerja mereka.

\section{Daftar Pustaka}

Abdulah, Budiman. (2019). Pengaruh Motivasi Dan Disiplin Kerja Terhadap Kinerja Karyawan Smk Ksatrya Jakarta. Jurnal Ekobis: Ekonomi, Bisnis \& Manajemen. Volume 9 Nomor 1

Ahyari, Agus. (2014). Manajemen Produksi: Pengendalian Produksi, Edisi 5, BPFE, Yogyakarta

Arikunto, Suharsimi. (1995). Manajemen Penelitian. Jakarta: Rineka Cipta

Bougie, \& Sekaran. (2013). Edisi 5, Research Methods for Business: A skill Building Approach. New York: John wiley@Sons

Ekhsan. (2017). Pengaruh Motivasi dan Disiplin Kerja Terhadap Kinerja Karyawan Pada Kinerja Karyawan Pada PT. Syncrum Logistics, Cikarang. Jurnal Optimal. Vol.13, No.1, 2019.

Hamalik. (1992). Media Pendidikan. Bandung: Penerbit Alumni

Hasibuan, Malayu. (2005). Manajemen Sumber Daya Manusia. Jakarta: Bumi Aksara Josephine, Harjanti. (2017). Pengaruh Lingkungan Kerja Terhadap Kinerja Karyawan Pada Bagian Produksi Melalui Motivasi Kerja Sebagai Variabel Intervening Pada PT. Trio Corporate Plastic (Tricopla), Surabaya. AGORA Vol. 5, No.3.

Kusjono, Ramasari. (2019). Pengaruh Motivasi dan Kompensasi Terhadap Kinerja Karyawan Pada Kinerja Karyawan Pada PT. Sumber Tenaga Lestari (Citylight Apartment), Tangerang Selatan. JENIUS. Vol. 2, No. 2, Januari 2019.

Kusniawati, Nurhayati dan Herlina. (2014). Pengaruh Lingkungan Kerja dan Disiplin Kerja Terhadap Kinerja Karyawan Pada PT. Gapuraning Rahayu, Ciamis. Jurnal Ekonologi IImu Manajemen. Vol.1, No. 1, April 2014.

Mangkunegara, Anwar Prabu. (2017). Manajemen Sumber Daya Manusia Perusahaan. Cetakan 14. PT.Remaja Rosdakarya. Bandung.

Moekijat. (2002). Dasar-dasar Motivasi. Jakarta: Pionis Jaya

Mulyasa, E. (2003). Managemen Berbasis Sekolah. Bandung : Penerbit PT Remaja Rosdakarya

Nitisemito, Alex S. (2014). Manajemen Personalia. Jakarta: Ghalia Indonesia

Novyanti, Joyce Sagita. (2015). Pengaruh Motivasi Berprestasi, Lingkungan kerja, Disiplin kerja Terhadap kinerja Pegawai pada Bappeda Provinsi Sulawesi Tengah. Jurnal Katalogis, vol 3, No. 1, Hal 113

Nuraini, T. (2013). Manajemen Sumber Daya Manusia, Yayasan Aini Syam: Pekanbaru

Pramadita, AA Gde Oka dkk . (2015). Pengaruh Motivasi Kerja, Disiplin Kerja, dan Lingkungan Kerja Terhadap Kinerja Karyawan pada PT PLN (Persero) Disitribusi di Denpasar Bali. E-Jurnal Manajemen. Vol. 4, No. 8. 29 Juni 2015

Prasetyo, Marlina. (2019). Pengaruh Disiplin Kerja dan Kepuasan Kerja Terhadap Kinerja Karyawan Motivasi dan Kompensasi Terhadap Kinerja Karyawan Pada Kinerja Karyawan di PT. Nihon Plast Indonesia, Bekasi. Jurnal Inspirasi Bisnis dan Manajemen, Vol 3, (1), 2019.

Robbin, P. Stephen. (2013). "Perilaku Organisasi, Alih Bahasa, Tim Indeks". Jakarta: Gramedya. 
Sardiman, A.M. (2006). Interaksi dan Motivasi Belajar Mengajar, Jakarta: PT. Raja Grafindo Persada

Siagian Sondang P., (2002). Kiat Meningkatkan Produktivitas Kerja, Cetakan Pertama, PT. Rineka Cipta, Jakarta

Sugiyono. (2010). "Metode Penelitian Bisnis". Bandung: Alfabeta.

Sutrisno, E. (2009). Manajemen Sumber Daya Manusia. Jakarta : Kencana

Suwanto. (2019). Pengaruh Disiplin Kerja dan Motivasi Kerja terhadap Kinerja Pada Rumah Sakit Umum, Tangerang Selatan. JENIUS. Vol. 3 No.1, September 2019.

Timpe, A Dale. (1992). Kinerja. Jakarta: PT. Gramedia 